\title{
PEMANFAATAN BUKU BAHASA INDONESIA PADA SKRIPSI FAKULTAS PERTANIAN IPB UNIVERSITY TAHUN 2015-2019 BERBASIS ANALISIS SITASI
}

\author{
Janti Gristinawati Sujana ${ }^{1}$ dan Didin Mulyadi $^{2}$ \\ Perpustakaan IPB University \\ 1jantigs@gmail.com,2dienmoe21@gmail.com
}

\begin{abstract}
Abstrak
Pendahuluan. Pengadaan koleksi perpustakaan haruslah efektif dan efisien. Selama ini diasumsikan bahwa mahasiswa IPB University lebih senang menggunakan buku-buku bahasa Indonesia, namun dari beberapa pengamatan pada koleksi buku cukup banyak buku-buku bahasa Indonesia yang catatan peminjamannya (slip tanggal kembali) dalam keadaan kosong. Artinya buku itu tidak pernah dipinjam oleh pengguna. Salah satu cara untuk mengukur keterpakaian koleksi adalah menggunakan analisis sitasi.

Tujuan. Penelitian ini bertujuan 1) mengetahui ketersediaan buku-buku bahasa Indonesia yang disitasi di skripsi Fakultas Pertanian IPB University 2015-2019 pada koleksi Perpustakaan IPB University; 2) mengidentifikasi buku bahasa Indonesia yang banyak dimanfaatkan mahasiswa Fakultas Pertanian IPB University pada skripsi tahun 2015-2019; 3) mengetahui rata-rata usia keusangan buku bahasa Indonesia yang disitasi dalam skripsi Fakultas Pertanian IPB University 2015-2019; 4) mengetahui penerbit buku bahasa Indonesia yang paling banyak disitasi oleh skripsi Fakultas Pertanian 2015-2019.

Metode. Penelitian ini merupakan penelitian kuantitatif, menggunakan salah satu metode bibliometrika, yaitu analisis sitasi. Pengumpulan data dilakukan dengan mengamati daftar pustaka pada setiap skripsi, semua buku bahasa Indonesia yang ada di daftar pustaka akan dicatat pada lembar catatan berbasis Excel.

Hasil. Hasil penelitian menunjukkan buku-buku bahasa Indonesia yang disitasi di skripsi Fakultas Pertanian IPB University 2015-2019 tersedia di koleksi Perpustakaan IPB University sebanyak 18,0 $\%$ untuk Departemen Ilmu Tanah dan Sumber Daya Lahan, 22,0 \% untuk Departemen Agronomi dan Hortikultura, 22,0 \% untuk Departemen Proteksi Tanaman dan 16,0 \% untuk Departemen Arsitektur Lanskap. Buku yang paling banyak disitasi berdasarkan departemen di Fakultas Pertanian adalah "Konservasi Tanah dan Air", "Teknik Pemuliaan Tanaman", "Pestisida dan Aplikasinya", dan "Pemeliharaan Taman". Keusangan buku-buku yang disitasi berada antara 12 15 tahun. Penerbit yang bukunya paling banyak disitasi adalah Gadjah Mada University Press, Kanisius dan Penebar Swadaya.
\end{abstract}

Kata kunci: Judul buku disitasi; ketersediaan buku; keusangan buku; penerbit buku; Perpustakaan IPB University

\footnotetext{
Abstract

Introduction. Procurement of library collections must be effective and efficient. So far, it has been assumed that IPB University students prefer to use Indonesian books, but from some observations on books collection, quite a lot of Indonesian books' due date slips are blank. This means that the book was never borrowed by the user. One way to measure the usability of a collection is to use citation analysis.

Objectives. This study aims to 1) determine the availability of Indonesian language books cited in the undergraduate theses of the Faculty of Agriculture IPB University 2015-2019 in the collection of the IPB University Library; 2) identify Indonesian language books that are widely used by students of IPB University, Faculty of Agriculture in writing undergraduate theses 20152019; 3) knowing the average age of obsolescence of Indonesian language books cited in the 20152019 IPB University, Faculty of Agriculture undergraduate theses; 4) find out which Indonesian language book publishers are cited the most by the 2015-2019 Faculty of Agriculture undergraduate theses.
} 
Methods. This research is a quantitative research, using one of the bibliometric methods, namely citation analysis. Data collection is done by observing the bibliography in each undergraduate thesis, all Indonesian books in the bibliography will be recorded on an Excel-based note sheet.

Results. The results showed that Indonesian language books cited in the undergraduate theses of the Faculty of Agriculture, IPB University 2015-2019 were available in the collections of the IPB University Library as much as $18.0 \%$ for the Department of Soil Science and Land Resources, $22.0 \%$ for the Department of Agronomy and Horticulture, $22.0 \%$ for the Department of Plant Protection and $16.0 \%$ for the Department of Landscape Architecture. The most cited books by undergraduate theses at the Faculty of Agriculture are "Soil and Water Conservation" for the Department of Soil Science and Land Resources, "Plant Breeding Techniques" for the Department of Agronomy and Horticulture, "Pesticides and Their Applications" for the Department of Plant Protection, and "Garden Maintenance" for the Department of Landscape Architecture. The obsolescence of the cited books is between 12-15 years. The publishers whose books have been cited the most are Gadjah Mada University Press, Kanisius and Penebar Swadaya.

Keywords: books available; books obsolescence; books’ publishers; cited book titles; IPB University Library

\section{Pendahuluan}

Koleksi perpustakaan merupakan salah satu komponen sangat penting untuk penyelenggaraan perpustakaan, karena pengguna datang ke perpustakaan utamanya untuk mecari informasi. Walaupun saat ini informasi tersedia begitu banyak di internet, dan prinsip perpustakaan era digital ini bukanlah kepemilikan koleksi, tetapi lebih pada akses pengguna terhadap informasi, tetap saja bahwa perpustakaan harus memiliki koleksi seperti diamanatkan oleh Undang-Undang Nomor 43 Tahun 2007 Pasal 15 ayat (3).

Perpustakaan selama ini selalu menghadapi kendala terkait dana pengadaan koleksi. Bila terjadi pengurangan dana pada lembaga induknya, hampir pasti perpustakaan akan dipotong jatah dananya. Sering juga terjadi dana untuk pengadaan koleksi tidak meningkat untuk waktu yang lama, padahal harga bahan perpustakaan setiap tahun terus meningkat. Pustakawan harus pandai-pandai menggunakan dana untuk pengadaan koleksi. Salah satu cara untuk penggunaan dana yang efisien dan efektif adalah dengan selalu mengevaluasi keterpakaian koleksi yang dimiliki. Banyak penelitian tentang evaluasi keterpakaian koleksi melalui analisis sitasi, seperti yang dilakukan Zulaikha dkk.
(2003), Erwina \& Yulianti (2012), Anggraini \& Bakhtaruddin (2013), Maryam (2015), Hayati (2016), Arif (2017), Himawanti \& Wijayanti (2018), Nurohman (2019), dan lain-lain. Arif (2017) meneliti keterpakaian koleksi Perpustakaan Fakultas Hukum Universitas Gadjah Mada (UGM) oleh mahasiswa Fakultas Hukum UGM dalam penulisan skripsi, tesis dan disertasi tahun 2016 menggunakan analisis sitasi. Hasil penelitian menunjukkan bahwa mayoritas literatur yang disitir mahasiswa adalah buku dan 64\% literatur yang disitasi tersedia di Perpustakaan Fakultas Hukum Universitas Gadjah Mada. Dalam rangka mengetahui tingkat keterpakaian koleksi Perpustakaan IAIN Purwokerto, Nurohman (2019) melakukan analisis sitasi pada skripsi mahasiswa Fakultas Ekonomi dan Bisnis Islam tahun 20102017. Hasil penelitian menunjukkan bahwa monograf berbahasa Indonesia lebih banyak dimanfaatkan, sedangkan pemanfaatan jurnal sangat kurang. Dana pengadaan untuk koleksi jurnal memang tidak memadai.

Pada kasus di IPB University, selama ini diasumsikan bahwa mahasiswa IPB University lebih menyukai membaca buku dalam bahasa Indonesia, karena pada umumnya mahasiswa mempunyai masalah dengan bahasa Inggris. Dari 
beberapa kali melakukan pengecekan pada catatan tanggal kembali peminjaman buku (slip tanggal kembali), cukup banyak buku-buku bahasa Indonesia tidak pernah dipinjam mahasiswa. Penelitian ini akan mengevaluasi keterpakaian bukubuku bahasa Indonesia yang menjadi koleksi Perpustakaan IPB University dalam penyusunan skripsi mahasiswa Fakultas Pertanian IPB University tahun 2015-2019. Keterpakaian buku-buku tersebut dapat diidentifikasi secara jelas melalui daftar pustaka, dan metode penelitian tersebut dikenal sebagai analisis sitasi, salah satu metode penelitian berbasis bibliometrika.

Banyak hal dapat diungkap melalui analisis sitasi, sehingga dapat dijadikan acuan ketika menentukan pengadaan buku untuk koleksi perpustakaan. Tujuan dari penelitian ini adalah (1) Mengetahui ketersediaan buku-buku bahasa Indonesia yang disitasi pada skripsi Fakultas Pertanian IPB University 20152019 di koleksi Perpustakaan IPB University; (2) Mengidentifikasi buku bahasa Indonesia yang banyak dimanfaatkan mahasiswa Fakultas Pertanian IPB University pada skripsi tahun 2015-2019; (3) Mengetahui ratarata usia keusangan buku bahasa Indonesia yang disitasi dalam skripsi Fakultas Pertanian IPB University 20152019; dan (4) Mengetahui penerbit buku bahasa Indonesia yang paling banyak disitasi oleh skripsi Fakultas Pertanian IPB University 2015-2019.

\section{METODE PENELITIAN}

Penelitian ini merupakan penelitian kuantitatif, menggunakan metode bibliometrika. Definisi bibliometrika menurut the British Standard (dalam Sulistyo-Basuki, 2002) adalah kajian penggunaan dokumen dan pola publikasi dengan menerapkan metode matematika dan statistika. Salah satu metode kajian berbasis bibliometrika adalah analisis sitasi. Apakah sitasi itu? Berdasarkan
Harrod's Library Glossary and Reference Book (1990 dalam Hayati, 2016) definisi dari sitasi adalah "suatu rujukan pada suatu teks atau bagian dari suatu teks yang menunjuk pada suatu dokumen dimana teks itu dimuat". Hartinah (2002) menjelaskan secara rinci sitasi sebagai berikut: "Ketika dokumen A disebut oleh dokumen B sebagai catatan kaki, catatan akhir, bibliografi atau daftar pustaka maka dikatakan bahwa dokumen A disitir oleh dokumen $\mathrm{B}$ dan dokumen $\mathrm{B}$ menyitir dokumen A". Menurut Angelsen \& Aryal (2005), pensitasian sebuah publikasi adalah sebuah pengakuan oleh sesama ilmuwan tentang kemanfaatan dan kualitas dari karya itu.

Selanjutnya, apakah analisis sitasi itu? Menurut Kumar \& Reddy (2012), "One method for tracking and evaluating research is citation analysis". Hayati (2016) menjelaskan bahwa analisis sitasi merupakan salah satu alat dalam mengevaluasi koleksi perpustakaan.Yang menjadi objek penelitian adalah skripsi Fakultas Pertanian IPB University tahun 2015-2019, terutama daftar pustakanya.

Adapun cara pengumpulan data kajian ini dengan mengamati daftar pustaka pada setiap skripsi, semua buku bahasa Indonesia yang ada di daftar pustaka akan dicatat pada lembar catatan berbasis Excel. Berdasarkan Kamus Besar Bahasa Indonesia (Kementerian Pendidikan dan Kebudayaan, 2016) buku adalah lembar kertas yang berjilid, berisi tulisan atau kosong. Jadi buku yang diterbitkan secara komersial ataupun tidak komersial seperti laporan penelitian, pedoman pelaksanaan atau petunjuk teknis, data statistik, prosiding termasuk dalam kajian ini. Namun buku dalam format digital yang dapat diakses di internet tidak termasuk yang didata dalam kajian ini.

Data buku yang dicatat adalah: a) Judul buku; b) Pengarang, termasuk badan korporasi bila bertindak sebagai creator, c) Tahun terbit; dan d) Penerbit. 
Kemudian data dari skripsi yang akan dicatat adalah: a) Judul skripsi; b) Nomor Induk Mahasiswa; c) Tahun dikeluarkannya skripsi; dan d) Nama departemen.

Hasil pengolahan dengan aplikasi Excel dapat dianalisis untuk menjawab semua tujuan penelitian. Daftar buku bahasa Indonesia yang diperoleh dari daftar pustaka skripsi akan dicocokkan dengan database koleksi buku bahasa Indonesia Perpustakaan IPB University, sehingga akan diketahui berapa persen dari buku-buku yang dimanfaatkan untuk menyusun skripsi ada di koleksi Perpustakaan IPB University.

\section{HASIL DAN PEMBAHASAN}

Hasil dan pembahasan kajian ini akan disajikan sesuai dengan urutan dari tujuan penelitian yang telah dirumuskan. Sebagai data awal, hasil identifikasi jumlah skripsi Fakultas Pertanian 2015-2019 berdasarkan departemen dan tahun disajikan pada Tabel 1. Jumlah skripsi yang menjadi objek kajian ini adalah 2045 judul skripsi.

Tabel 1 Jumlah Skripsi Fakultas Pertanian 2015-2019 Berdasarkan Departemen dan Tahun

\begin{tabular}{|l|r|r|r|r|r|r|}
\hline \multicolumn{1}{|c|}{ Departemen } & \multicolumn{1}{|c|}{$\mathbf{2 0 1 5}$} & \multicolumn{1}{|c|}{$\mathbf{2 0 1 6}$} & \multicolumn{1}{c|}{$\mathbf{2 0 1 7}$} & \multicolumn{1}{c|}{$\mathbf{2 0 1 8}$} & \multicolumn{1}{c|}{$\mathbf{2 0 1 9}$} & Jumlah \\
\hline Ilmu Tanah dan Sumber Daya Lahan & 95 & 75 & 78 & 100 & 68 & 416 \\
\hline Agronomi dan Hortikultura & 159 & 153 & 214 & 181 & 121 & 828 \\
\hline Proteksi Tanaman & 74 & 72 & 97 & 108 & 71 & 422 \\
\hline Arsitektur Lanskap & 54 & 81 & 63 & 94 & 87 & 379 \\
\hline Total & 382 & 381 & 452 & 483 & 347 & 2045 \\
\hline
\end{tabular}

1. Ketersediaan Buku yang Disitasi pada Koleksi Perpustakaan IPB University

Temuan pertama yang dibahas adalah persentase ketersediaan buku- buku bahasa Indonesia yang disitasi oleh skripsi Fakultas Pertanian IPB University tahun 2015-2019 pada koleksi Perpustakaan IPB University. Hasil temuan disajikan pada Tabel 2.

Tabel 2. Ketersediaan buku yang disitasi pada koleksi Perpustakaan IPB University berdasarkan departemen

\begin{tabular}{|c|l|r|}
\hline No. & \multicolumn{1}{|c|}{ Departemen } & Ketersediaan (\%) \\
\hline 1 & Ilmu Tanah dan Sumber Daya Lahan & 18,0 \\
\hline 2 & Agronomi dan Hortikultura & 22,0 \\
\hline 3 & Proteksi Tanaman & 22,0 \\
\hline 4 & Arsitektur Lanskap & 16,0 \\
\hline
\end{tabular}

Ketersediaan buku-buku bahasa Indonesia yang disitasi skripsi Fakultas Pertanian IPB University 2015-2019 pada koleksi Perpustakaan IPB University sangat rendah. Berdasarkan pengamatan pada judul-judul buku yang disitasi, banyak buku-buku tersebut merupakan hasil penelitian dari perguruan tinggi, instansi penelitian terutama di bawah Kementerian Pertanian dan kementerian lainnya, serta petunjuk teknis dari kementerian terkait. Banyak buku-buku yang disitasi merupakan pustaka kelabu, tidak beredar di pasaran, sehingga sulit diperoleh. Kemudian banyak terbitan Badan Pusat Statistik, baik dari pusat maupun daerah, menjadi rujukan skripsiskripsi tersebut. Buku-buku terbitan Badan Pusat Statistik daerah hanya dapat diperoleh di Badan Pusat Statistik setempat.

Pada kasus skripsi Departemen Arsitektur Lanskap banyak buku-buku yang disitasi terkait dengan kebudayaan, seni dan ilmu-ilmu sosial lainnya yang selama ini dianggap bukan bidang ilmu 
yang menjadi ranah sivitas akademika IPB University. Dengan demikian di masa yang akan datang hal itu perlu menjadi perhatian dalam pengadaan koleksi Perpustakaan IPB University.

\section{Judul Buku yang Paling Banyak Disitasi}

Temuan kedua dari kajian ini adalah judul buku yang paling banyak disitasi skripsi Fakultas Pertanian IPB University tahun 2015-2019. Beberapa tabel di bawah ini menyajikan judul-judul buku yang paling banyak disitasi skripsi Fakultas Pertanian 2015-2019. Data tersebut disajikan berdasarkan departemen di Fakultas Pertanian IPB University, dengan urutan sesuai dengan urutan yang digunakan pada Nomor
Induk Mahasiswa (NIM) Fakultas Pertanian IPB University. Pada setiap tabel, kolom jumlah menunjukkan jumlah sitasi terhadap judul buku tersebut, dan di banyak kasus dapat juga menunjukkan jumlah skripsi yang mensitasi judul buku itu. Fakta di pendataan memang kadangkadang ada skripsi yang mensitasi judul yang sama dengan tahun terbit yang berbeda, tetapi kebanyakan satu judul buku disitasi satu kali pada satu judul skripsi.

\section{a. Departemen Ilmu Tanah dan Sumber Daya Lahan}

Tabel 3 menampilkan 15 judul buku yang paling banyak disitasi skripsi Departemen Ilmu Tanah dan Sumber Daya Lahan, Fakultas Pertanian IPB University 2015-2019.

Tabel 3. Judul buku Bahasa Indonesia yang paling banyak disitasi skripsi Departemen Ilmu Tanah dan Sumber Daya Lahan

\begin{tabular}{|c|c|c|c|c|c|}
\hline No. & Judul & Pengarang & Thn & Penerbit & Jmlh \\
\hline 1 & Konservasi Tanah dan Air & Arsyad S & 2010 & IPB Press & 139 \\
\hline 2 & Sifat dan Ciri Tanah & Soepardi G & 1983 & $\begin{array}{l}\text { Jurusan Tanah, } \\
\text { Fakultas Pertanian, } \\
\text { Institut Pertanian } \\
\text { Bogor }\end{array}$ & 122 \\
\hline 3 & Ilmu Tanah & Hardjowigeno S & $\begin{array}{r}1983- \\
2010\end{array}$ & $\begin{array}{l}\text { Akademika } \\
\text { Pressindo }\end{array}$ & 113 \\
\hline 4 & $\begin{array}{l}\text { Evaluasi Kesesuaian Lahan dan } \\
\text { Perencanaan Tataguna Lahan }\end{array}$ & $\begin{array}{l}\text { Hardjowigeno S dan } \\
\text { Widiatmaka }\end{array}$ & 2007 & $\begin{array}{l}\text { Gadjah Mada } \\
\text { University Press }\end{array}$ & 55 \\
\hline 5 & Kimia Tanah & Anwar S, Sudadi U & 2013 & $\begin{array}{l}\text { Departemen Ilmu } \\
\text { Tanah dan } \\
\text { Sumberdaya Lahan. } \\
\text { Fakultas Pertanian. } \\
\text { IPB }\end{array}$ & 49 \\
\hline 6 & Dasar-dasar Ilmu Tanah & Hanafiah KA & 2005 & $\begin{array}{l}\text { Raja Grafindo } \\
\text { Persada }\end{array}$ & 47 \\
\hline 7 & $\begin{array}{l}\text { Petunjuk Teknis Analisis Kimia } \\
\text { Tanah, Tanaman, Air dan Pupuk , }\end{array}$ & $\begin{array}{l}\text { Balai Penelitian Tanah, } \\
\text { Badan Penelitian dan } \\
\text { Pengembangan } \\
\text { Pertanian }\end{array}$ & 2005 & $\begin{array}{l}\text { Departemen } \\
\text { Pertanian }\end{array}$ & 42 \\
\hline 8 & Kesuburan tanah & $\begin{array}{l}\text { Leiwakabessy FM, } \\
\text { Sutandi A }\end{array}$ & 1988 & $\begin{array}{l}\text { Departemen Ilmu } \\
\text { Tanah dan } \\
\text { Sumberdaya Lahan } \\
\text { IPB }\end{array}$ & 42 \\
\hline 9 & $\begin{array}{l}\text { Hidrologi dan Pengelolaan Daerah } \\
\text { Aliran Air Sungai }\end{array}$ & Asdak C & 2004 & $\begin{array}{l}\text { Gadjah Mada } \\
\text { University Press }\end{array}$ & 41 \\
\hline 10 & $\begin{array}{l}\text { Penginderaan Jauh dan Intepretasi } \\
\text { Citra }\end{array}$ & $\begin{array}{l}\text { Lillesand TM, Kiefer } \\
\text { RW }\end{array}$ & 1979 & $\begin{array}{l}\text { Gajah Mada } \\
\text { University Press }\end{array}$ & 38 \\
\hline 11 & Klasifikasi Tanah dan Pedogenesis & Hardjowigeno S & 1993 & $\begin{array}{l}\text { Akademika } \\
\text { Pressindo }\end{array}$ & 37 \\
\hline 12 & $\begin{array}{l}\text { Perencanaan dan Pengembangan } \\
\text { Wilayah }\end{array}$ & $\begin{array}{l}\text { Rustiadi E, S Saeful } \\
\text { Hakim, DR Panuju }\end{array}$ & 2006 & $\begin{array}{l}\text { Fakultas Pertanian, } \\
\text { Institut Pertanian } \\
\text { Bogor }\end{array}$ & 36 \\
\hline
\end{tabular}




\begin{tabular}{|c|l|l|c|l|r|}
\hline No. & \multicolumn{1}{|c|}{ Judul } & \multicolumn{1}{|c|}{ Pengarang } & Thn & \multicolumn{1}{|c|}{ Penerbit } & Jmlh \\
\hline 13 & Pupuk Organik dan Pupuk Hayati & $\begin{array}{l}\text { Balai Besar Penelitian } \\
\text { Pengembangan } \\
\text { Sumberdaya Lahan }\end{array}$ & 2006 & $\begin{array}{l}\text { Balai Besar } \\
\text { Penelitian } \\
\text { Pengembangan } \\
\text { Sumberdaya Lahan }\end{array}$ & 32 \\
\hline 14 & $\begin{array}{l}\text { Analisis Kimia Tanah, Tanaman Air } \\
\text { dan Pupuk }\end{array}$ & Balai Penelitian Tanah & 2009 & $\begin{array}{l}\text { Balai Penelitian } \\
\text { Tanah }\end{array}$ & 32 \\
\hline 15 & Dasar-Dasar Ilmu Tanah & $\begin{array}{l}\text { Hakim N, Nyakpa MY, } \\
\text { Lubis AM, Nugraha SG, } \\
\text { Saul MR, Diha MA, } \\
\text { Hong GB, dan Bailey } \\
\text { HH }\end{array}$ & 1986 & $\begin{array}{l}\text { Universitas } \\
\text { Lampung Press }\end{array}$ & 31 \\
\hline
\end{tabular}

Buku "Konservasi Tanah dan Air" yang dikarang oleh Sitanala Arsyad dan diterbitkan oleh IPB Press merupakan buku yang paling banyak disitasi skripsi Departemen Ilmu Tanah dan Sumber Daya Lahan, Fakultas Pertanian IPB University 2015-2019. Buku tersebut telah diterbitkan sejak akhir tahun 1970an dan buku yang disitasi pada skripsi departemen tersebut sangat beragam tahun terbitnya.

Yang perlu juga menjadi catatan, dari 15 judul buku yang paling banyak disitasi, ada tiga judul buku dikarang oleh Sarwono Hardjowigeno, yaitu buku "Ilmu Tanah", "Evaluasi Kesesuaian Lahan dan Perencanaan Tataguna Lahan", dan "Klasifikasi Tanah dan Pedogenesis". Dari 15 judul buku yang paling banyak disitasi tersebut, ternyata hanya dua penerbit yang merupakan penerbit komersial yaitu Akademika
Pressindo dan Raja Grafindo Persada. IPB Press, Gadjah Mada University Press dan Universitas Lampung Press walaupun termasuk penerbit bersifat komersial, tetapi ketiganya merupakan penerbit perguruan tinggi negeri yang tidak terlalu berorientasi pada aspek komersial. Dari 15 judul buku itu, tiga judul buku dikeluarkan oleh Departemen Ilmu Tanah dan Sumber Daya Lahan Fakultas Pertanian IPB University, walaupun ada satu nama berbeda karena pada masa itu departemen masih bernama Jurusan Ilmu Tanah. Dari Kementerian Pertanian dan instansi yang berada di bawahnya ada tiga judul buku, walaupun pada saat itu masih bernama Departemen Pertanian dan instansi di bawahnya ada kemungkinan berubah juga namanya.

\section{b. Departemen Agronomi dan Hortikultura}

Tabel 4 menyajikan 15 judul buku yang paling banyak disitasi skripsi Departemen Agronomi dan Hortikultura

Tabel 4. Judul buku bahasa Indonesia yang paling banyak disitasi skripsi Departemen Agronomi dan Hortikultura

\begin{tabular}{|c|l|l|c|l|c|}
\hline No. & \multicolumn{1}{|c|}{ Judul } & \multicolumn{1}{|c|}{ Pengarang } & Thn & \multicolumn{1}{|c|}{ Penerbit } & Jmlh \\
\hline 1 & Teknik Pemuliaan Tanaman & $\begin{array}{l}\text { Syukur M, Sujiprihati S, } \\
\text { Yunianti R }\end{array}$ & $\begin{array}{l}2012, \\
2015\end{array}$ & $\begin{array}{l}\text { Penebar } \\
\text { Swadaya }\end{array}$ & 139 \\
\hline 2 & $\begin{array}{l}\text { Perancangan Percobaan dengan } \\
\text { Aplikasi SAS dan Minitab }\end{array}$ & Mattjik AA, IM Sumertajaya & 2000 & IPB Press & 108 \\
\hline 3 & Dasar Ilmu dan Teknologi Benih & $\begin{array}{l}\text { Widajati E, Muniarti E, } \\
\text { Palupi ER, Suharsi TK, } \\
\text { Suhartanto MR dan Qadir A }\end{array}$ & 2012 & IPB Press & 85 \\
\hline 4 & $\begin{array}{l}\text { Prosedur Statistik untuk } \\
\text { Penelitian Pertanian }\end{array}$ & Gomez KA, Gomez AA & 1995 & UI Press & 69 \\
\hline 5 & $\begin{array}{l}\text { Ilmu Tanah } \\
\text { Parameter Pengujian Vigor Benih } \\
\text { dari Komparatif ke Simulatif }\end{array}$ & Sadjad S, Murniati E, Ilyas S & 1989 & $\begin{array}{l}\text { Akademik } \\
\text { a } \\
\text { Pressindo }\end{array}$ & 64 \\
\hline
\end{tabular}




\begin{tabular}{|c|c|c|c|c|c|}
\hline No. & Judul & Pengarang & Thn & Penerbit & Jmlh \\
\hline 7 & Dari Benih Kepada Benih & Sadjad S & 1993 & Grasindo & 43 \\
\hline 8 & Buku Pintar Kelapa Sawit & Lubis RE, A Widanarko & 2008 & $\begin{array}{l}\text { Agromedia } \\
\text { Pustaka }\end{array}$ & 41 \\
\hline 9 & $\begin{array}{l}\text { Kelapa Sawit (Elaeis guineensis } \\
\text { Jacq) di Indonesia Edisi II }\end{array}$ & Lubis AU & 2008 & $\begin{array}{l}\text { Pusat } \\
\text { Penelitian } \\
\text { Kelapa } \\
\text { Sawit }\end{array}$ & 40 \\
\hline 10 & $\begin{array}{l}\text { Budidaya Tanaman Padi di } \\
\text { Indonesia }\end{array}$ & Siregar $\mathrm{H}$ & 1978 & $\begin{array}{l}\text { Sastra } \\
\text { Hudaya }\end{array}$ & 34 \\
\hline 11 & $\begin{array}{l}\text { Bioteknologi dalam Pemuliaan } \\
\text { Tanaman }\end{array}$ & $\begin{array}{l}\text { Wattimena GA, Wiendi } \\
\text { NMA, Mattjik NA, Purwito } \\
\text { A, Efendi D, Purwoko BS, } \\
\text { dan Khumaida N }\end{array}$ & 2011 & IPB Press & 34 \\
\hline 12 & Panduan Lengkap Kelapa Sawit & Pahan 1 & 2008 & $\begin{array}{l}\text { Penebar } \\
\text { Swadaya }\end{array}$ & 32 \\
\hline 13 & $\begin{array}{l}\text { Budidaya } 8 \text { Jenis Tanaman } \\
\text { Pangan Unggul }\end{array}$ & Purwono, H Purnamawati & 2007 & $\begin{array}{l}\text { Penebar } \\
\text { Swadaya }\end{array}$ & 32 \\
\hline 14 & Teknologi Hortikultura & Poerwanto R, AD Susila & 2014 & IPB Press & 31 \\
\hline 15 & Budidaya Kelapa Sawit & Pusat Penelitian Kelapa Sawit & 2007 & $\begin{array}{l}\text { Pusat } \\
\text { Penelitian } \\
\text { Kelapa } \\
\text { Sawit } \\
\end{array}$ & 31 \\
\hline
\end{tabular}

Buku yang paling banyak disitasi adalah "Teknik Pemuliaan Tanaman" dikarang oleh M. Syukur, S. Sujiprihati dan R. Yunianti, serta diterbitkan oleh Penebar Swadaya. Dari 15 buku yang paling banyak disitasi skripsi Departemen Agronomi dan Hortikultura ada empat judul buku diterbitkan oleh IPB Press dan tiga buku diterbitkan oleh Penebar Swadaya. Pada skripsi departemen ini ada delapan buku paling banyak disitasi diterbitkan oleh penerbit komersial dan dua buku dikeluarkan oleh instansi di bawah Kementerian Pertanian.
Pengarang Sjamsoe'oed Sadjad mempunyai dua judul buku yang banyak disitasi, yaitu "Parameter Pengujian Vigor Benih dari Komparatif ke Simulatif" (ditulis bersama dengan E. Murniati dan S. Ilyas) dan "Dari Benih Kepada Benih". c. Departemen Proteksi Tanaman

Tabel 5 menyajikan 16 judul buku yang paling banyak disitasi pada skripsi Departemen Proteksi Tanaman. Data yang diambil 16 judul buku karena pada peringkat ke 14, 15 dan 16 jumlah sitasi pada judul-judul buku tersebut sama yaitu 10 sitasi.

Tabel 5. Judul buku bahasa Indonesia yang paling banyak disitasi skripsi Departemen Proteksi Tanaman

\begin{tabular}{|c|c|c|c|c|c|}
\hline No. & Judul & Pengarang & Thn & Penerbit & Jmlh \\
\hline 1 & Pestisida dan Aplikasinya & Djojosumarto P & 2008 & AgroMedia Pustaka & 29 \\
\hline 2 & $\begin{array}{l}\text { Pengantar Pengelolaan } \\
\text { Hama Terpadu }\end{array}$ & Untung $\mathrm{K}$ & 1993 & Gadjah Mada University Press & 28 \\
\hline 3 & $\begin{array}{l}\text { Penyakit-penyakit Tanaman } \\
\text { Perkebunan di Indonesia }\end{array}$ & Semangun $\mathrm{H}$ & 1988 & Gadjah Mada University Press & 19 \\
\hline 4 & $\begin{array}{l}\text { Insektisida Nabati: Prinsip } \\
\text { Pemanfaatan dan } \\
\text { Pengembangan }\end{array}$ & Dadang, Prijono D & 2008 & $\begin{array}{l}\text { Departemen Proteksi Tanaman } \\
\text { Institut Pertanian Bogor }\end{array}$ & 18 \\
\hline 5 & $\begin{array}{l}\text { Pengenalan Pelajaran } \\
\text { Serangga }\end{array}$ & $\begin{array}{l}\text { Borror DJ, } \\
\text { Triplehorn CA, } \\
\text { Johnson NF }\end{array}$ & 1996 & Gadjah Mada University Press & 17 \\
\hline 6 & $\begin{array}{l}\text { Pengantar Ilmu Penyakit } \\
\text { Tumbuhan }\end{array}$ & Semangun $\mathrm{H}$ & 1991 & Gadjah Mada University Press & 17 \\
\hline 7 & $\begin{array}{l}\text { Penyakit-Penyakit Tanaman } \\
\text { Hortikultura di Indonesia }\end{array}$ & Semangun $\mathrm{H}$ & 1994 & Gadjah Mada University Press & 16 \\
\hline
\end{tabular}




\begin{tabular}{|c|c|c|c|c|c|}
\hline 8 & $\begin{array}{l}\text { Mikrobiologi Dasar dalam } \\
\text { Praktek }\end{array}$ & Hadioetomo RS & 1993 & Gramedia Pustaka Utama & 16 \\
\hline 9 & $\begin{array}{l}\text { Dasar-Dasar Ilmu Penyakit } \\
\text { Tumbuhan Edisi ke-2 }\end{array}$ & Sinaga MS & 2006 & Penebar Swadaya & 14 \\
\hline 10 & $\begin{array}{l}\text { Pestisida Pertanian dan } \\
\text { Kehutanan }\end{array}$ & $\begin{array}{l}\text { Kementerian } \\
\text { Pertanian Republik } \\
\text { Indonesia }\end{array}$ & 2012 & $\begin{array}{l}\text { Kementerian Pertanian Republik } \\
\text { Indonesia }\end{array}$ & 13 \\
\hline 11 & $\begin{array}{l}\text { Pengendalian Hama Tikus } \\
\text { Terpadu }\end{array}$ & Priyambodo S & 2003 & Penebar Swadaya & 13 \\
\hline 12 & Nematologi Pertanian & Mulyadi & 2009 & Gadjah Mada University Press & 13 \\
\hline 13 & $\begin{array}{l}\text { Penerapan Teknologi PHT } \\
\text { pada Tanaman Kubis }\end{array}$ & $\begin{array}{l}\text { Sastrosiswojo S, } \\
\text { Tinny SU, } \\
\text { Rachmat S }\end{array}$ & 2005 & $\begin{array}{l}\text { Balai Penelitian Tanaman } \\
\text { Sayuran }\end{array}$ & 11 \\
\hline 14 & $\begin{array}{l}\text { Pengendalian Hama } \\
\text { Terpadu dan } \\
\text { Implementasinya di } \\
\text { Indonesia }\end{array}$ & Oka IN & 1995 & Gadjah Mada University Press & 10 \\
\hline 15 & $\begin{array}{l}\text { Pengantar Pengendalian } \\
\text { Hayati Penyakit Tanaman }\end{array}$ & Soesanto L & 2008 & Raja Grafindo Persada & 10 \\
\hline 16 & Kubis & $\begin{array}{l}\text { Permadi AH, } \\
\text { Sastrosiswojo S }\end{array}$ & 1993 & $\begin{array}{l}\text { Badan Penelitian dan } \\
\text { Pengembangan Pertanian dan } \\
\text { Balai Penelitian Hortikultura }\end{array}$ & 10 \\
\hline
\end{tabular}

Buku berjudul "Pestisida dan Aplikasinya" dikarang oleh P. Djojosumarto dan diterbitkan oleh Agromedia Pustaka merupakan buku yang paling banyak disitasi skripsi Departemen Proteksi Tanaman. Gadjah Mada University Press mendominasi buku-buku yang banyak disitasi skripsi Departemen Proteksi Tanaman, ada tujuh judul buku terbitan Gadjah Mada University Press yang banyak disitasi. Sementara itu ada lima penerbit komersial yang bukunya banyak disitasi, dan satu judul buku dikeluarkan oleh Kementerian Pertanian dan dua judul buku dikeluarkan oleh instansi di bawah Kementerian Pertanian.

Jumlah sitasi pada judul buku tertentu di skripsi Departemen Proteksi Tanaman paling tinggi mencapai 29 sitasi, tidak seperti pada kasus di skripsi Departemen Ilmu Tanah dan Sumber Daya Lahan dan skripsi Departemen
Agronomi dan Hortikultura dimana ada ratusan sitasi pada judul buku tertentu. Seorang pengarang bernama Haryono Semangun mempunyai tiga judul buku yang banyak disitasi oleh skripsi Departemen Proteksi Tanaman, dan ketiga judul buku tersebut diterbitkan oleh Gadjah Mada University Press.

\section{d. Departemen Arsitektur Lanskap}

Tabel 6 menyajikan 16 judul buku yang paling banyak disitasi oleh skripsi Departemen Arsitektur Lanskap. Untuk departemen ini diambil 16 judul, karena judul ke 13, 14, 15 dan 16 jumlah sitasinya sama, yaitu 13 sitasi. Pada skripsi Departemen Arsitektur Lanskap ini jumlah sitasi pada satu judul buku tertentu juga maksimum hanya mencapai 46 sitasi. Selain itu jumlah sitasi pada buku tertentu ada beberapa yang sama, seperti yang terjadi pada judul ke 4-5, 8-10, dan 13-16.

Tabel 6. Judul buku bahasa Indonesia yang paling banyak disitasi skripsi Departemen Arsitektur Lanskap

\begin{tabular}{|c|l|l|c|l|r|}
\hline No. & \multicolumn{1}{|c|}{ Judul } & \multicolumn{1}{|c|}{ Pengarang } & Thn & \multicolumn{1}{|c|}{ Penerbit } & Jml \\
\hline 1 & Pemeliharaan Taman & Arifin HS, Arifin NHS & 2005 & Penebar Swadaya & 46 \\
\hline & $\begin{array}{l}\text { Perencanaan Kawasan untuk } \\
\text { Pelestarian Lanskap dan Taman } \\
\text { Sejarah }\end{array}$ & $\begin{array}{l}\text { Nurisjah S, } \\
\text { Pramukanto Q }\end{array}$ & 2001 & $\begin{array}{l}\text { Departemen } \\
\text { Arsitektur Lanskap } \\
\text { Fakultas Pertanian } \\
\text { Institut Pertanian } \\
\text { Bogor }\end{array}$ & 27 \\
\hline
\end{tabular}




\begin{tabular}{|c|c|c|c|c|c|}
\hline No. & Judul & Pengarang & Thn & Penerbit & Jml \\
\hline 3 & $\begin{array}{l}\text { Komponen Perancangan Arsitektur } \\
\text { Lansekap }\end{array}$ & Hakim R & 2012 & Bumi Aksara & 26 \\
\hline 4 & $\begin{array}{l}\text { Tata Cara Perencanaan Teknik } \\
\text { Lansekap Jalan }\end{array}$ & $\begin{array}{l}\text { Direktorat Jenderal } \\
\text { Bina Marga }\end{array}$ & 1996 & $\begin{array}{l}\text { Departemen } \\
\text { Pekerjaan Umum }\end{array}$ & 24 \\
\hline 5 & $\begin{array}{l}\text { Analisis SWOT : Teknik } \\
\text { Membedah Kasus Bisnis }\end{array}$ & Rangkuti F & 1997 & $\begin{array}{l}\text { Gramedia Pustaka } \\
\text { Utama }\end{array}$ & 24 \\
\hline 6 & $\begin{array}{l}\text { Pengantar kepada Arsitektur } \\
\text { Pertamanan }\end{array}$ & Laurie M & 1986 & Intermatra & 22 \\
\hline 7 & $\begin{array}{l}\text { Daya Dukung dalam Perencanaan } \\
\text { Tapak }\end{array}$ & $\begin{array}{l}\text { Nurisjah S, } \\
\text { Pramukanto Q }\end{array}$ & 2003 & $\begin{array}{l}\text { Departemen } \\
\text { Arsitektur Lanskap } \\
\text { Fakultas Pertanian } \\
\text { Institut Pertanian } \\
\text { Bogor } \\
\end{array}$ & 20 \\
\hline 8 & Ekologi Hutan & Indriyanto Ir & 2006 & Bumi Aksara & 16 \\
\hline 9 & $\begin{array}{l}\text { Evaluasi Kesesuaian Lahan dan } \\
\text { Perencanaan Tata guna Lahan }\end{array}$ & $\begin{array}{l}\text { Hardjowigeno S dan } \\
\text { Widiatmaka }\end{array}$ & 2007 & $\begin{array}{l}\text { Gadjah Mada } \\
\text { University Press }\end{array}$ & 16 \\
\hline 10 & $\begin{array}{l}\text { Tantangan Lingkungan dan } \\
\text { Lansekap Hutan Kota }\end{array}$ & Irwan ZD & 2005 & Bumi Aksara & 16 \\
\hline 11 & $\begin{array}{l}\text { Prinsip-prinsip Dasar } \\
\text { Mengkonservasi Lanskap }\end{array}$ & Fandeli C, Muhammad & 2009 & $\begin{array}{l}\text { Gadjah Mada } \\
\text { University Press } \\
\end{array}$ & 15 \\
\hline 12 & $\begin{array}{l}\text { Pembangunan Kawasan dan Tata } \\
\text { Ruang }\end{array}$ & Adisasmita $\mathrm{R}$ & 2010 & Graha Ilmu & 14 \\
\hline 13 & $\begin{array}{l}\text { Sampoerna Hijau Kotaku Hijau : } \\
\text { Buku Panduan Penataan Taman } \\
\text { Umum, Penanaman Tanaman, } \\
\text { Penanganan Sampah dan } \\
\text { Pemberdayaan Masyarakat Jakarta }\end{array}$ & $\begin{array}{l}\text { Arifin HS, Munandar } \\
\text { A, Arifin NHS, } \\
\text { Pramukanto Q, } \\
\text { Damayanti VD }\end{array}$ & 2008 & Sampoerna Hijau & 13 \\
\hline 14 & RTH 30\%! Resolusi (Kota) Hijau & Joga N, Ismaun I & 2011 & $\begin{array}{l}\text { Gramedia Pustaka } \\
\text { Utama }\end{array}$ & 13 \\
\hline 15 & Galeri Tanaman Hias Lanskap & Lestari G, Kencana IP & 2008 & Penebar Swadaya & 13 \\
\hline 16 & $\begin{array}{l}\text { Daya Tarik dalam Pengelolaan } \\
\text { Agrowisata }\end{array}$ & $\begin{array}{l}\text { Tirtawinata M R dan } \\
\text { Fachruddin L }\end{array}$ & 1996 & Penebar Swadaya & 13 \\
\hline
\end{tabular}

Judul buku yang paling banyak disitasi oleh skripsi Departemen Arsitektur Lanskap Fakultas Pertanian IPB University berjudul "Pemeliharaan Taman" dikarang oleh Hadi Susilo Arifin dan Nurhayati HS. Arifin, serta diterbitkan oleh Penebar Swadaya. Pada skripsi Departemen Arsitektur Lanskap ini buku-buku yang banyak disitasi dominan diterbitkan oleh penerbit komersial. Ada 10 judul buku berasal dari penerbit komersial, tiga judul buku diantaranya berasal dari Penebar Swadaya, tiga judul buku lainnya berasal dari Bumi Aksara, dan dua buku diantaranya berasal dari Gramedia Pustaka Utama. Dua judul buku yang banyak disitasi berasal dari Departemen Arsitektur Lanskap Fakultas Pertanian
IPB University, dan keduanya dikarang oleh Siti Nurisjah dan Qodarian Pramukanto. Penerbit Gadjah Mada University Press mempunyai dua judul buku yang banyak disitasi di skripsi Departemen Arsitektur Lanskap.

Dengan mengamati judul-judul buku yang paling banyak disitasi pada masing-masing departemen, Tabel 7 menyajikan judul buku yang paling banyak digunakan, dan digunakan oleh lebih dari satu departemen. Sebenarnya mungkin banyak judul-judul buku yang sama yang digunakan oleh beberapa departemen, tetapi kajian ini hanya mengamati pada judul-judul buku yang paling banyak digunakan oleh keempat departemen tersebut. 
Tabel 7. Judul buku bahasa Indonesia yang paling banyak disitasi oleh lebih dari satu departemen

\begin{tabular}{|l|l|l|l|l|}
\hline \multicolumn{1}{|c|}{ Judul Buku } & \multicolumn{1}{c|}{ Pengarang } & \multicolumn{1}{c|}{ Penerbit } & Thn & \multicolumn{1}{c|}{ Departemen } \\
\hline $\begin{array}{l}\text { Evaluasi Kesesuaian } \\
\text { Lahan dan Perencanaan } \\
\text { Tata Guna Lahan }\end{array}$ & $\begin{array}{l}\text { Hardjowigeno S dan } \\
\text { Widiatmaka }\end{array}$ & $\begin{array}{l}\text { Gadjah Mada } \\
\text { University Press }\end{array}$ & 2007 & $\begin{array}{l}\text { Ilmu Tanah dan Sumber } \\
\text { Daya Lahan; Arsitektur } \\
\text { Lanskap }\end{array}$ \\
\hline Ilmu Tanah & Hardjowigeno S & $\begin{array}{l}\text { Akademika } \\
\text { Pressindo }\end{array}$ & $\begin{array}{l}1983- \\
2010\end{array}$ & $\begin{array}{l}\text { Ilmu Tanah dan Sumber } \\
\text { Daya Lahan; Agronomi dan } \\
\text { Hortikultura }\end{array}$ \\
\hline
\end{tabular}

Temuan dari kajian ini ada dua judul buku yang digunakan oleh masingmasing dua departemen, dan kedua judul itu terkait ilmu tanah, dikarang oleh Sarwono Hardjowigeno, walaupun salah satu judul hasil kerja sama dengan penulis Widiatmaka.

\section{Rata-rata Usia Keusangan Buku yang Disitasi}

Tabel 8. Rata-rata usia keusangan buku bahasa Indonesia yang disitasi

\begin{tabular}{|c|c|c|}
\hline No. & Departemen & $\begin{array}{c}\text { Rata-rata Usia } \\
\text { Keusangan }\end{array}$ \\
\hline 1 & Ilmu Tanah dan Sumber Daya Lahan & 15 \\
\hline 2 & Agronomi dan Hortikultura & 12 \\
\hline 3 & Proteksi Tanaman & 12 \\
\hline 4 & Arsitektur Lanskap & 13 \\
\hline
\end{tabular}

Dari Tabel 8 ternyata rata-rata usia buku yang disitasi pada skripsi Fakultas Pertanian IPB University tahun 20152019 di atas 10 tahun. Yang paling tua adalah dari Departemen Ilmu Tanah dan Sumber Daya Lahan. Hal itu menunjukkan bahwa buku-buku yang diterbitkan di atas 10 tahun substansinya
Temuan kajian yang ketiga adalah rata-rata usia keusangan buku-buku yang disitasi skripsi Fakultas Pertanian IPB University tahun 2015-2019. Tabel 8 menyajikan data rata-rata usia keusangan buku-buku yang disitasi berdasarkan departemen di lingkungan Fakultas Pertanian IPB University.

Tabel 9. Buku yang disitasi dengan tahun terbit tertua

\begin{tabular}{|c|c|c|c|c|c|}
\hline No. & Departemen & Judul Buku & Pengarang & Penerbit & Tahun \\
\hline 1 & $\begin{array}{l}\text { Ilmu Tanah dan Sumber } \\
\text { Daya Lahan }\end{array}$ & Ilmu Tubuh Tanah I & N.W. Wirjodihardjo & Noordhoff-kolff & 1953 \\
\hline \multirow[t]{2}{*}{2} & $\begin{array}{l}\text { Agronomi dan } \\
\text { Hortikultura }\end{array}$ & Pemuliaan Tanaman & R.W. Allard & Rineka Cipta & 1960 \\
\hline & $\begin{array}{l}\text { Agronomi dan } \\
\text { Hortikultura }\end{array}$ & $\begin{array}{l}\text { Bunga Anggrek Permata } \\
\text { Belantara Indonesia }\end{array}$ & S.M. Latif & Sumur & 1960 \\
\hline 3 & Proteksi Tanaman & $\begin{array}{l}\text { Memberantas Hama- } \\
\text { hama Djeruk }\end{array}$ & Tjoa T.M. & $\begin{array}{l}\text { Pusat Djawatan } \\
\text { Pertanian } \\
\text { Rakyat }\end{array}$ & 1956 \\
\hline 4 & Arsitektur Lanskap & $\begin{array}{l}\text { De Batoe-Toelis bij } \\
\text { Buitenzorg }\end{array}$ & R.Ng. Poerbatjaraka & BGKW & 1921 \\
\hline
\end{tabular}

Tabel 9 menyajikan buku-buku yang paling tua yang disitasi skripsi berdasarkan departemen. Satu judul lebih mengena pada masalah kajian skripsi-skripsi tersebut atau para penulis skripsi tidak mendapat akses pada bukubuku yang baru yang kebanyakan adalah pustaka kelabu dalam format laporan penelitian atau petunjuk teknis dari kementerian. 
Departemen Ilmu Tanah dan Sumber Daya Lahan, ada tiga judul skripsi mensitasi satu buku yang diterbitkan oleh penerbit yang masih menggunakan nama Belanda. Pada skripsi Departemen Agronomi dan Hortikultura ditemukan dua judul buku paling tua, keduanya diterbitkan tahun 1960. Buku "Bunga Anggrek Permata Belantara Indonesia" yang dikarang oleh S.M. Latif disitasi oleh dua skripsi. Pada satu judul skripsi Departemen Proteksi Tanaman mensitasi satu judul buku yang ditulis dalam bahasa Indonesia ejaan lama.

\section{Penerbit Paling Banyak Disitasi}

Tabel 10. Penerbit yang bukunya paling banyak disitasi skripsi Departemen Ilmu Tanah dan Sumber Daya Lahan

\begin{tabular}{|c|c|c|}
\hline No. & Nama Penerbit & Jumlah \\
\hline 1 & Gadjah Mada University Press & 372 \\
\hline 2 & Badan Pusat Statistik & 261 \\
\hline 3 & IPB Press & 247 \\
\hline 4 & Jurusan Tanah. Fakultas Pertanian. Institut Pertanian Bogor & 194 \\
\hline 5 & $\begin{array}{l}\text { Balai Besar Litbang Sumberdaya Lahan Pertanian. Badan Penelitian dan } \\
\text { Pengembangan Pertanian. Departemen Pertanian }\end{array}$ & 126 \\
\hline 6 & Akademika Pressindo & 120 \\
\hline 7 & Penebar Swadaya & 113 \\
\hline 8 & Kanisius & 95 \\
\hline 9 & Raja Grafindo Persada & 77 \\
\hline 10 & Institut Pertanian Bogor & 56 \\
\hline 11 & Bumi Aksara & 51 \\
\hline 12 & UI Press & 47 \\
\hline 13 & Balai Penelitian Tanah & 41 \\
\hline 14 & Pustaka Buana & 37 \\
\hline 15 & Rineka Cipta & 34 \\
\hline
\end{tabular}

Pada skripsi Departemen Ilmu Tanah dan Sumber Daya Lahan penerbit yang buku-bukunya paling banyak disitasi adalah Gadjah Mada University Press, yaitu 372 sitasi. Di peringkat kedua ada Badan Pusat Statistik yang terbitannya mendapat 261 sitasi dari skripsi-skripsi Departemen Ilmu Tanah dan Sumber Daya Lahan. Kebanyakan skripsi memerlukan dukungan data statistik untuk tempat penelitiannya dari Badan Pusat Statistik pusat atau daerah. Di peringkat ketiga ada IPB Press dimana buku-buku terbitannya mendapat 247 sitasi oleh skripsi Departemen Ilmu
Temuan kajian yang keempat adalah penerbit yang bukunya paling banyak disitasi oleh skripsi Fakultas Pertanian IPB University tahun 20152019. Penentuan penerbit yang bukubukunya paling banyak disitasi dibahas berdasarkan departemen asal dari skripsinya.

\section{a. Departemen Ilmu Tanah dan Sumber Daya Lahan}

Tabel 10 menyajikan data 15 penerbit yang bukunya paling banyak disitasi skripsi Departemen Ilmu Tanah dan Sumber Daya Lahan Fakultas Pertanian 2015-2019.
Tanah dan Sumber Daya Lahan. Dari 15 penerbit yang buku-bukunya banyak disitasi skripsi Departemen Ilmu Tanah dan Sumber Daya Lahan, tujuh diantaranya adalah penerbit komersial, tiga penerbit perguruan tinggi negeri, dan ada dua instansi di bawah Kementerian Pertanian.

\section{b. Departemen Agronomi dan Hortikultura}

Tabel 11 menyajikan 15 penerbit yang buku-bukunya paling banyak disitasi skripsi Departemen Agronomi dan Hortikultura. 
Tabel 11. Penerbit yang bukunya paling banyak disitasi skripsi Departemen Agronomi dan Hortikultura

\begin{tabular}{|c|l|r|}
\hline No. & \multicolumn{1}{|c|}{ Nama Penerbit } & Jumlah \\
\hline 1 & Penebar Swadaya & 960 \\
\hline 2 & IPB Press & 590 \\
\hline 3 & Kanisius & 565 \\
\hline 4 & Agromedia Pustaka & 380 \\
\hline 5 & Gajahmada University Press & 237 \\
\hline 6 & Pusat Penelitian Kelapa Sawit. Medan & 204 \\
\hline 7 & Gramedia Pustaka Utama & 178 \\
\hline 8 & Badan Metereologi, Klimatologi, dan Geofisika & 175 \\
\hline 9 & Balai Penelitian Tanaman Sayuran, Lembang & 162 \\
\hline 10 & UI Press & 159 \\
\hline 11 & Raja Grafindo Persada & 152 \\
\hline 12 & Grasindo & 128 \\
\hline 13 & Pusat Penelitian dan Pengembangan Tanaman pangan. Badan & 118 \\
\hline 14 & Benelitian dan Pengembangan Pertanian & 108 \\
\hline 15 & Bumi Aksara & 99 \\
\hline
\end{tabular}

\section{Pada skripsi Departemen}

Agronomi dan Hortikultura penerbit yang buku-bukunya paling banyak disitasi adalah Penebar Swadaya, yaitu sebanyak 960 sitasi. Di peringkat kedua ada IPB Press, dimana buku-bukunya mendapat 590 sitasi dari skripsi departemen tersebut. Gadjah Mada University Press buku-bukunya juga banyak disitasi, hanya kali ini ada di peringkat kelima. Dengan demikian ada tiga penerbit perguruan tinggi, yaitu IPB Press, Gadjah Mada University Press, dan UI Press yang masuk dalam 15 penerbit mendapat paling banyak sitasi. Dari Kementerian Pertanian ada empat instansi, dari Badan Penelitian dan Pengembangan Pertanian dan tiga instansi penelitian di bawahnya. Sementara itu ada tujuh penerbit komersial yang buku-bukunya banyak disitasi oleh skripsi Departemen Agronomi dan Hortikultura.

\section{c. Departemen Proteksi Tanaman}

Tabel 12 menyajikan 15 penerbit yang buku-bukunya paling banyak disitasi skripsi-skripsi Departemen Proteksi Tanaman.

Tabel 12. Penerbit yang bukunya paling banyak disitasi skripsi Departemen Proteksi Tanaman

\begin{tabular}{|c|l|r|}
\hline No. & \multicolumn{1}{|c|}{ Nama Penerbit } & Jumlah \\
\hline 1 & Gadjah Mada University Press & 197 \\
\hline 2 & Penebar Swadaya & 107 \\
\hline 3 & Kanisius & 89 \\
\hline 4 & $\begin{array}{l}\text { Balai Penelitian Tanaman Sayuran Pusat Penelitian dan } \\
\text { Pengembangan Hortikultura Badan Penelitian dan Pengembangan Pertanian }\end{array}$ & 62 \\
\hline 5 & Agromedia Pustaka & 58 \\
\hline 6 & Badan Pusat Statistik & 49 \\
\hline 7 & Balai Besar Penelitian Tanaman Padi & 36 \\
\hline 8 & Kementrian Pertanian Republik Indonesia & 33 \\
\hline 9 & Badan Litbang Pertanian Pusat Penelitian dan Pengembangan Tanaman Pangan & 30 \\
\hline 10 & Balai Pengkajian Teknologi Pertanian Sumatera Utara & 27 \\
\hline 11 & Gramedia Pustaka Utama & 25 \\
\hline 12 & Direktorat Jenderal Perkebunan & 25 \\
\hline 13 & UI-Press & 22 \\
\hline 14 & Raja Grafindo Persada & 22 \\
\hline 15 & Departemen Proteksi Tanaman, IPB & 20 \\
\hline
\end{tabular}


Pada skripsi dari Departemen Proteksi Tanaman penerbit Gadjah Mada University Press kembali menjadi penerbit yang buku-bukunya paling banyak disitasi. IPB Press tidak termasuk dalam 15 penerbit yang bukunya paling banyak disitasi, namun UI Press masih termasuk kedalam 15 besar. Dari IPB University hanya Departemen Proteksi Tanaman Fakultas Pertanian IPB University yang buku-bukunya termasuk dalam 15 penerbit besar, itu pun ada di peringkat ke 15. Kementerian Pertanian berada di peringkat kedelapan dan ada lima instansi di bawahnya yang bukubukunya banyak disitasi skripsi Departemen Proteksi Tanaman. Sementara itu ada lima penerbit komersial termasuk dalam penerbit yang bukubukunya banyak disitasi skripsi Departemen Proteksi Tanaman.

\section{d. Departemen Arsitektur Lanskap}

Tabel 13 menyajikan 15 penerbit yang buku-bukunya paling banyak disitasi oleh skripsi Departemen Arsitektur Lanskap.

Tabel 13. Penerbit yang bukunya paling banyak disitasi skripsi Departemen Arsitektur Lanskap

\begin{tabular}{|c|l|r|}
\hline No. & \multicolumn{1}{|c|}{ Nama Penerbit } & Jumlah \\
\hline 1 & Badan Pusat Statistik & 247 \\
\hline 2 & Bumi Aksara & 163 \\
\hline 3 & Penebar Swadaya & 155 \\
\hline 4 & Gramedia Pustaka Utama & 132 \\
\hline 5 & Gajah Mada University Press & 128 \\
\hline 6 & Departemen Arsitektur Lanskap; Fakultas Pertanian; Institut Pertanian Bogor & 97 \\
\hline 7 & IPB Press & 95 \\
\hline 8 & Andi Offset & 88 \\
\hline 9 & Badan Perencanaan Pembangunan Daerah & 77 \\
\hline 10 & Erlangga & 67 \\
\hline 11 & Kanisius & 58 \\
\hline 12 & Institut Pertanian Bogor & 49 \\
\hline 13 & Departemen Pekerjaan Umum, Direktorat Jenderal Bina Marga & 48 \\
\hline 14 & Intermatra & 47 \\
\hline 15 & Pradnya Paramita & 44 \\
\hline
\end{tabular}

\section{Pada skripsi Departemen}

Arsitektur Lanskap penerbit yang terbitannya paling banyak disitasi adalah Badan Pusat Statistik, yaitu 247 sitasi. Di peringkat kedua penerbit Bumi Aksara dan ketiga penerbit Penebar Swadaya. Kali ini Gadjah Mada University Press tetap masuk dalam 15 besar, menduduki peringkat kelima dan IPB Press berada di peringkat ketujuh. Pada skripsi Departemen Arsitektur Lanskap, UI Press tidak termasuk dalam 15 penerbit yang bukunya paling banyak disitasi.

Penerbit yang masuk dalam 15 penerbit dengan buku-bukunya paling banyak disitasi oleh skripsi Departemen Arsitektur Lanskap ada sedikit perbedaan. Ada Badan Perencanaan Pembangunan Daerah yang buku-bukunya banyak disitasi. Diduga mahasiswa yang akan membuat desain taman dan penataan lingkungan di suatu daerah, harus merujuk pada dokumen yang dikeluarkan oleh Badan Perencanaan Pembangunan Daerah setempat, agar desainnya tidak melenceng dari perencanaan yang sudah ada di daerah tersebut. Kemudian ada Departemen Pekerjaan Umum, Direktorat Jenderal Bina Marga termasuk dalam 15 besar penerbit. Diduga mahasiswa kalau mau membuat desain memerlukan rujukan ke buku-buku atau petunjuk teknis yang dikeluarkan oleh Departemen Pekerjaan Umum, Direktorat Jenderal Bina Marga.

Departemen Arsitektur Lanskap sendiri menduduki peringkat keenam dengan 97 sitasi. Sementara itu ada delapan penerbit komersial yang masuk dalam 15 penerbit yang buku-bukunya 
banyak disitasi skripsi Departemen Arsitektur Lanskap. Kali ini Kementerian Pertanian dan instansi di bawahnya tidak masuk kedalam 15 penerbit yang terbanyak disitasi buku-bukunya.

Berdasarkan pengamatan pada penerbit yang buku-bukunya paling banyak disitasi pada empat departemen di Fakultas Pertanian IPB University, penerbit Gadjah Mada University Press, Kanisius dan Penebar Swadaya masuk sebagai 15 penerbit dengan bukubukunya terbanyak disitasi pada skripsi keempat departemen di Fakultas Pertanian IPB University. Buku-buku bahasa Indonesia yang disitasi skripsi Fakultas Pertanian IPB University tahun 2015-2019 sangat beragam, namun bila dilihat dari penerbit yang buku-bukunya paling banyak disitasi pada skripsi berdasarkan departemen, ternyata semuanya ada 36 penerbit. Dari 36 penerbit itu, hanya 14 penerbit yang merupakan penerbit yang benar-benar komersial. Kemudian ada 11 penerbit merupakan instansi dari Kementerian Pertanian dan instansi penelitian di bawahnya. Penerbit perguruan tinggi yang buku-bukunya banyak disitasi adalah Gadjah Mada University Press, IPB Press, dan UI Press, namun Gadjah Mada University Press lebih dominan dibandingkan bahkan dengan IPB Press. Buku-buku yang banyak disitasi keluaran unit-unit di IPB sendiri hanya berasal dari empat unit, jauh di bawah instansi Kementerian Pertanian yang mencapai 11 instansi.

\section{KESIMPULAN}

Temuan hasil kajian ini didasarkan pada rumuan masalah dapat disimpulkan sebagai berikut:

1. Ketersediaan buku-buku bahasa Indonesia yang disitasi skripsi empat departemen Fakultas Pertanian IPB University 2015-2019 di koleksi Perpustakaan IPB University rendah, yaitu antara $16-22 \%$. Salah satu sebabnya mungkin karena banyak buku yang disitasi merupakan pustaka kelabu dan tahun terbit yang agak lama namun spesifik buku-buku pertanian.

2. Judul buku yang paling banyak disitasi skripsi Departemen Ilmu Tanah dan Sumber Daya Lahan adalah "Konservasi Tanah dan Air" dikarang oleh Sitanala Arsyad dan diterbitkan IPB Press; pada Departemen Agronomi dan Hortikultura adalah "Teknik Pemuliaan Tanaman" dikarang oleh M. Syukur, S. Sujiprihati, R. Yunianti dan diterbitkan oleh Penebar Swadaya; pada Departemen Proteksi Tanaman adalah "Pestisida dan Aplikasinya" dikarang oleh P. Djojosumarto diterbitkan oleh AgroMedia Pustaka; dan pada skripsi Departemen Arsitektur Lanskap adalah "Pemeliharaan Taman" dikarang oleh Hadi Susilo Arifin dan Nurhayati H.S. Arifin diterbitkan oleh Penebar Swadaya. Ada dua judul buku termasuk dalam buku yang paling banyak disitasi, dan disitasi oleh lintas departemen. Kedua buku itu adalah "Evaluasi Kesesuaian Lahan dan Perencanaan Tata Guna Lahan" dikarang oleh Sarwono Hardjowigeno dan Widiatmaka; dan "Ilmu Tanah" dikarang oleh Sarwono Hardjowigeno.

3. Rata-rata usia keusangan buku-buku yang disitasi skripsi Fakultas Pertanian IPB University 2015-2019 bervariasi dari $12-15$ tahun pada keempat departemen. Ada kemungkinan buku-buku lama tersebut substansinya lebih sesuai dengan kebutuhan kajian penulis skripsi atau karena para penulis skripsi tidak mempunyai akses ke buku-buku yang lebih baru.

4. Penerbit yang buku-buku terbitannya paling banyak disitasi, untuk Departemen Ilmu Tanah dan 
Sumber Daya Lahan adalah Gadjah Mada University Press; untuk Departemen Agronomi dan Hortikultura adalah Penebar Swadaya; untuk Departemen Proteksi Tanaman adalah Gadjah Mada University Press; dan untuk Departemen Arsitektur Lanskap adalah Badan Pusat Statistik. Penerbit Gadjah Mada University Press, Penebar Swadaya dan Kanisius merupakan penerbit yang bukubukunya banyak disitasi oleh skripsi keempat departemen Fakultas Pertanian IPB University tahun 2015-2019.

\section{REKOMENDASI}

1. Perpustakaan IPB University perlu lebih memperkaya koleksinya dengan buku-buku dari pustaka kelabu dan buku-buku spesifik pertanian dalam bahasa Indonesia, walau dari tahun yang lama, bila tahun terbit yang baru belum tersedia di pasaran.

2. Judul buku-buku yang paling banyak disitasi pada skripsi Fakultas Pertanian 2015-2019, bila belum ada di koleksi Perpustakaan perlu mendapat perhatian untuk diadakan di masa depan. Buku-buku tersebut ada kemungkinan masih dibutuhkan oleh generasi berikutnya, yang melakukan penulisan skripsi pada setiap departemen.

3. Perpustakaan perlu berusaha untuk mendapatkan buku-buku yang dimanfaatkan dalam penulisan skripsi Fakultas Pertanian IPB University tahun 2015-2019 untuk tahun terbit yang lebih baru. Berbagai pustaka kelabu terbaru, terutama keluaran Kementerian Pertanian dan berbagai instansi di bawahnya dan Badan Pusat Statistik sangat perlu diadakan di masa depan.

4. Pada pengadaan buku-buku bahasa Indonesia di masa depan perlu memperhatikan buku-buku terbitan penerbit yang berdasarkan kajian ini banyak disitasi skripsi keempat departemen Fakultas Pertanian IPB University.

\section{DAFTAR PUSTAKA}

Angelsen, A. \& Aryal, B. (2005). Contributing to the scientific literature: Citation analysis of CIFOR publications. Bogor: CIFOR.

Anggraini, L. \& Bakhtaruddin. (2013). Evaluasi ketersediaan koleksi dengan menggunakan analisis sitiran terhadap tesis mahasiswa Pascasarjana Program Studi Ilmu Biomedik tahun 2012 di Perpustakaan Fakultas Kedokteran Universitas Andalas. Jurnal Ilmu Informasi Perpustakaan dan Kearsipan Seri C. 2(1): 159-168. http://ejournal.unp.ac. id/index.php/iipk/article/viewFile/2319/1 936

Arif, I. (2017). Pemanfaatan koleksi Perpustakaan Fakultas Hukum Universitas Gadjah Mada untuk karya akhir mahasiswa: kajian analisis sitasi. Berkala Ilmu Perpustakaan dan Informasi. 13(2): 155165. DOI: http://10.22146/bip.27494.

Erwina, W. \& Yulianti. (2012). Kajian sitasi karya ilmiah dosen Fikom Unpad dalam skripsi mahasiswa: analisis sitasi karya ilmiah dosen dalam skripsi mahasiswa pada database GDL di Fikom Library and Knowledge Center (FLKC) Universitas Padjadjaran pada semester genap tahun 2011. EduLib. 2(2): 139-157.

Hartinah, S. (2002). Analisis sitiran (citation analysis). Dalam: Kumpulan makalah kursus bibliometrika. Pusat Studi Jepang, UI Depok, 20 -23 Mei 2002. Depok: Masyarakat Informetrika Indonesia.

Hayati, N. (2016). Analisis sitiran sebagai alat evaluasi koleksi perpustakaan. Record and Library Journal. 2(1): 1-15.

Himawanti \& Wijayanti, L. (2018). Pengembangan koleksi untuk program internasionalisasi jurnal bidang geosains di Indonesia: analisis sitasi. Khizanah alHikmah : Jurnal Ilmu Perpustakaan, Informasi, dan Kearsipan, 6(1), 55-66. DOI: $10.24252 /$ kah.v6a1a6

Kementerian Pendidikan dan Kebudayaan RI. (2016). Kamus Besar Bahasa Indonesia. https://kbbi.kemdikbud.go.id/entri/buku

Kumar, K. \& Reddy, T.R. (2012). Citation analysis of dissertations submitted to the Department of Library and Information Science, Sri Venkateswara University, Tirupati. International Journal of Digital Library Services. 2(2): 44-58. 
Maryam, S. (2015). Evaluasi koleksi Perpustakaan UIN Jakarta berdasar analisis sitiran penelitian para dosen. Jakarta: Pusat Penelitian dan Penerbitan, LP2M UIN Syarif Hidayatullah.

http://repository.uinjkt.ac.id/dspace/bits tream/123456789/29673/1/ SITI\%20MARYAN-FAH-2015.pdf

Nurohman, A. (2019). Evaluasi koleksi literatur ekonomi dan perbankan melalui analisis sitasi skripsi mahasiswa Fakultas Ekonomi dan Bisnis Islam IAIN Purwokerto tahun 2010-2017. Media Pustakawan. 26(2): 98108.
Sulistyo-Basuki. (2002). Bibliometrika, sainsmetrika dan informetrika. Dalam: Kumpulan makalah kursus bibliometrika. Pusat Studi Jepang, UI - Depok, 20 -23 Mei 2002. Depok: Masyarakat Informetrika Indonesia.

Zulaikha, S.R., Dwiyanto, A., Septiyantono, T. (2003). Evaluasi pemanfaatan koleksi dengan menggunakan analisis sitasi (Studi analisis sitasi skripsi mahasiswa di Perpustakaan Pusat IAIN Sunan Kalijaga Yogyakarta). Berkala Ilmu Perpustakaan dan Informasi. 1(1): 28-35. 